\title{
㐘周病の病因におけるサイトカインの意義 Pathophysiological roles of cytokines in periodontal disease
}

大阪大学大学院歯学研究科 口腔分子免疫制御学講座歯周病分子病態学 村上伸也

歯周病の原因となるデンタルプラークは歯周ポケット内, すなわち生体外に存在するため, 免疫系 の働きによるプラークの完全な排除は期待できない。そのため, 我々の宿主細胞は, 歯周組織に慢性 的に加えられる細菌刺激に対して応答しょうとするものの，その刺激源がいつまでも除去されないた めに，持続的な，または過剰な免疫応答・炎症反応を歯周組織において継続することとなる。今日で はこのようなメカニズムによって歯周組織の破壊が進行するものと考えられている。この局所で繰り 広げられる生体応答の制御の中核をなすサイトカインに関する情報は同部の病態を理解する上で欠く ことができない。炎症歯周組織におけるサイトカイン産生に関しては，歯周外科時に採取された歯肉 組織片や歯肉溝浸出液 (GCF) 等が検体として用いられ, 種々の炎症性サイトカイン産生の定性的・ 定量的解析がなされてきた。しかしながら，その結果をもとにして，予見性をもった病態診断を行う には末だ不十分な段階にあるといわざるをえない。一方，これまでの我々の研究結果より，歯周病の 病態診断を行うには，複数の炎症性因子の発現を総合的に評価することが必須であることが示唆され ている。しかしながら，上述した従来の解析方法では複数の因子を総合的に検討することは極めて困 難であるといわざるをえない。

我々の研究室では, needle punch biopsy を開発し，歯周組織にほとんど損傷を加えることなく微 量歯肉組織（約 $1 \mathrm{mg}$ ）を採取し，同組織中に含まれる種々のタンパク質をコードする mRNA の発 現状況を RT-PCR 法を用いて解析する検査法を新たに確立した。その結果，得られた微量歯肉組織 1 検体から 20 種以上の mRNA 発現を一度に検査することが可能になった。この手法を用いて, 臨 床的に成人性歯周炎 (AP), 早期発症型歯周炎 (EOP) と診断された歯周炎患者の歯肉組織に打ける 複数の炎症関連因子の mRNA 発現プロフィールを解析し, クラスター分析によりグループ化するこ とを試みた。その結果, サイトカイン発現プロフィールによって歯周病の炎症パターンが 4 つのクラ スター（グループ）に分かれることが明らかとなった。とりわけ興味深いことに，EOP 患者におい ては IL-8，および IFN $\gamma$ の mRNA 発現が他のサイトカイン mRNA 発現に比し相対的に低下して いる特徵的なパターンを示す例が多数存在することが示唆された。この結果は, 臨床的な炎症所見で は区別の付かない病態がサイトカイン mRNA 発現プロフィールの解析により, さらに詳細に分類さ れうる可能性を示唆している。今後, これら各クラスター間の疾病活動度の差異を検討する予定であ るが，これらの情報は，個々の病変の病態解析，ひいてはそれに基づく特異的な host modulating drug の開発にもつながっていくものと期待している。

一方，種々の疾患に対する宿主間の感受性の差異をサイトカインの観点から明らかにしようとする 研究も進められている。IL-1 などの炎症性サイトカインをコードする遺伝子領域の解析結果より, それらの領域に遺伝子多型性が存在し，その多型性が各々の炎症性サイトカインのタンパク質レベル での産生量の差異をもたらしていること，また，IL-1 高産生性の遺伝子型が白人アメリカ人におけ る成人性歯周炎の重篤度に影響を及济す危険因子のひとつであることが報告されている。残念なが ら, 我々の研究結果によると, 日本人の中等度から重度の歯周炎患者が上記の IL-1 遺伝子型を有す る比率は, 健康な歯周組織を有する対照群に比して必ずしも高くないことが現段階では示されてい る。この点に関しては，日本人の歯周炎に対する易罹患性，重篤度に影響を及ぼす他の遺伝的要因が 存在しうることを念頭に置きつつ，今後さらに症例数を増加させ，最終的な結論を得る必要があると 考えている。 